\title{
YOUNG PEOPLE AND THE PSYCHOLOGICAL ORIENTATION TOWARDS POLITICS (POTP): IDENTIFYING GENDER, ETHNICITY, AND EDUCATIONAL BACKGROUND AS PREDICTORS
}

\author{
Indro Adinugroho ${ }^{1 *}$; Dhevy Setya Wibawa ${ }^{2}$ \\ ${ }^{1}$ Center for Political and Human Behavior Studies, Faculty of Psychology, Atma Jaya Catholic University of Indonesia \\ ${ }^{2}$ Faculty of Psychology, Atma Jaya Catholic University of Indonesia \\ Jl. Jend. Sudirman No. 51, Karet Semanggi, Setiabudi, Jakarta 12930, Indonesia \\ 1indro.adinugroho@atmajaya.ac.id; ${ }^{2}$ dhevy.wibawa@atmajaya.ac.id
}

Received: $03^{\text {rd }}$ March 2021/ Revised: $29^{\text {th }}$ April 2021/ Accepted: $04^{\text {th }}$ May 2021

\begin{abstract}
How to Cite: Adinugroho, I. \& Wibawa, D. S. (2021). Young people and the Psychological Orientation towards Politics (POTP): Identifying gender, ethnicity, and educational background as predictors. Humaniora, 12(3), 217-224.

https://doi.org/10.21512/humaniora.v12i3.7103
\end{abstract}

\begin{abstract}
The research addressed a psychological orientation of young people towards politics (Psychological Orientation towards Politics/POTP). It focused on three primary variables: Political Efficacy (PE), Political Interest (PI), and Political Knowledge (PK) in relation to gender identity (male and female), ethnicity (Tionghoa \& non-Tionghoa), and educational background (socio-political science and non-socio-political science). As a young democratic country, Indonesia faced various challenges while pursuing robust democracy like another developed country. One big challenge faced by Indonesia was related to the awareness of political participation, the most central element for a democratic country where people must be aware that they have legitimate power. To overcome these challenges, investigation on variables related to psychological dimensions of humans was needed to start developing a behavioral map of political behavior in Indonesia, particularly concentrating on young people as the next generation of Indonesia democracy. Data were collected from the online panel. Results from descriptive statistics and linear regression models with three blocks have shown that these three variables have played an important role in determining POTP in young people. PK is the most affected variable compared to the other two variables. In conclusion, the identification of ethnicity (Tionghoa vs. non-Tionghoa) and educational background are possible factors that may affect the degree of POTP in the female group.
\end{abstract}

Keywords: POTP, gender identification, ethnicity identification, educational background

\section{INTRODUCTION}

In 2018, The Economist finally released the 2017 World Democracy Index entitled Free Speech under Attack where in this report, democracy in Indonesia is still categorized as a flawed democracy, positioned in $71^{\text {st }}$ rank along with Afghanistan, Fiji, and Hong Kong. Flawed democracy itself refers to a form of a democratic country which still vulnerable to threat and political turbulence (The Economist, 2018). Some of the indicators applied in the index are (1) electoral process and pluralism, (2) functioning of government, (3) political participation, (4) political culture, and (5) civic liberties. The analysis from this index has told, in general, there is a problem in 'free speech' or the independence of individuals and/or groups to speak on their opinion towards the nation. Basically, this issue has become a challenge since the establishment of Indonesia as an independent country. The moment called 'reformation' from 1998 until 1999 becomes the crucial moment for Indonesia to readdress the basic principle of Indonesia's ideology as a democratic country (Ekayanta, 2019). The principle of democracy is covered by state ideology, namely Undang-Undang Dasar (UUD) 1945, which consists of the basic principle of good governance. However, there are still many challenges faced by Indonesia until now, such as political prejudice, propaganda, 
and black campaign when the election comes. As the highest administrator, the government should seriously consider this issue to improve Indonesia's democracy because the central element of democracy relies on the people to actively participate in politics.

The democracy index released by The Economist has informed people and many political scientists who are interested in Indonesia's issue that faces serious challenges on the people and its participation in politics. In reality, there are many political conflicts in Indonesia caused by the unreadiness of the public to receive a loss in many democratic battles. Often, those conflicts emerge after the election in the regional district, for example, in Papua district and East Java (Antara, 2017; Suryowati, 2017; Meiliana, 2018). Then, the readiness to see politics as an instrument of change is needed for all Indonesian citizens. Political participation covers many areas of human behavior, such as awareness of politics, the will to internalize politics as an instrument of change, and numerous forms of behavior that might be related to voting behavior. In an empirical definition, participation in politics refers to a form of behavior in the society to influence policies and regulations (Dalton, 2009; Ekman \& Amna, 2012). This form of behavior can occur depending on the context, culture, and how citizens frame politics in their minds. One of the variables that can influence political participation is a Psychological Orientation Towards Politics (POTP). Burns, Schlozman, and Verba (2001) have identified POTP with three behavioral dimensions. Those dimensions refer to Political Knowledge (PK), Political Interest (PI), and Political Efficacy (PE). Few studies have shown that these three variables could act as solid predictors towards political participation (Galston, 2001; Zaheer, 2016; Dahl, Abdelzadeh, \& Sohl, 2018). Based on the definition of these three, PK refers to a cognitive component of politics, PI refers to an emotion that drives people to participate in politics, and PE refers to belief related to politics as a tool for change. These three variables are psychological capital which encourages people to move and become active citizens in the nation, especially for democratic countries.

Even though Indonesia has declared democracy as the national principle embedded in the constitutional mandate since its independence in 1945 , the implementation of 'real democracy' just started since the reformation in 1999 where Soeharto was abdicated as Indonesia's President. This reformation has brought several consequences in its form as a democratic country. The most fundamental change is the new regulation for election, where the members of parliament, local leaders (Governor, Mayor, and Regent), and President and Vice President are elected directly by citizens (Fossati, 2016). After that, several changes in regulation and direction of the country are made, including a decentralization system and also the principle of good governance, which is based on transparency and accountability, where all the government data can be accessed by the public.
These attempts are made to facilitate people to control government through an open and transparent system (i.e., open data to be analyzed by the public as material to criticize government). However, to construct solid participation is not easy, like flipping the hand. Citizens must have a clear sense of urgency on this behavior which finally can lead them to act in public. POTP is the empirical variable that can explain the term sense of urgency in public due to its nature as well-rounded variables. It fills all the psychological components of humans, emotion, cognitive, and attitude.

In the perspective of political psychology, many studies have explored the importance of PP (Flavin \& Keane, 2012; de Zuniga, Diehl, \& Ardevol-Abreu, 2017) and also POTP (Galston, 2001; Strabac \& Allberg, 2011; Johann, 2012; Coffe, 2013; Dejaeghere \& van Erkel, 2017) for democratic countries, where these two variables are significant aspects to form robust and healthy democracy. In the psychological description, these two behaviors will emerge due to internal factors, such as cognitive capacity (Aars \& Christensen, 2020), emotion (Valentino et al., 2011), psychological well-being (Sulemana \& Agyapong, 2019), personality (Pruysers, Blais, \& Chen, 2019) and other internal psychological factors. However, in order to generate robust democracy, people should have awareness not just for ordinary participation but should be Voluntary Participation (VP). This type of participation requires a clear psychological orientation in seeing politics as an instrument to change (Burns, Schlozman \& Verba, 2001). The three dimensions of POTP are functioned as an enabler to lead people to participate in politics with a specific purpose. Unfortunately, empowering POTP is not like buying things; it is a long investment to make. Then, starting to invest those dimensions in young people is one of the alternatives for a democratic country to achieve more sustainable democracy in the future. As a consequence, many studies to investigate the current condition of POTP in Indonesia are needed to map Indonesia's political direction.

Assessing the current condition of POTP is the first and crucial step to plan investment for Indonesia. As well as other democratic countries, challenges always exist in managing a democratic society. In this research, the researchers try to replicate several studies (Verba, Burns, \& Schlozman, 1997; Coffe, 2013), which examine gender as a serious challenge in the democratic country, even in a democratic country which categorized as a developed country. Researchers are focusing attention on examining the gap of POTP between males and females in each dimension. Gender (male vs. female) becomes the focus in this research due to several data, which have indicated the gender gap phenomenon in Indonesia's political situation. National survey data collected by the Indonesia National Statistical Agency (BPS) in 2017 has shown a significant difference between the numbers of male and female legislators before and after the reformation. From the data, it is shown that from 1955 to 2014 , over $90 \%$ of legislators in the 
parliament were dominated by males. Another fact, from the first independence until now, Indonesia has only had one female President, namely Megawati Soekarno Putri. This gender gap truly brings some political consequences in developing policies and programs based on gender equality principles. Besides that, without proper equality between males and females in government, the principle of democracy will not be strong enough to declare.

Numbers of studies have shown that gender difference has played a significant role in the political environment (Verba, Burns, \& Schlozman, 1997; Dolan, 2011; Coffe, 2013). Research from Verba, Burns, and Schlozman (1997), for example, has shown that females are less politically interested, informed, and efficacious than the male group in the United States. This difference gap will affect females to be active in various political environments (i.e., voting, joining a political party, and criticizing government). Another advance research from Ferrin, Fraile, and Garcia-Albacete (2019) has shown that even though several policies have been developed in Finland and Spain to break the gender gap in politics, women are still insufficient to completely bridge the gender gap in political knowledge during adulthood. By utilizing data from a survey which assessing citizen's political knowledge in two countries $(n=1020)$, the result shows that females tend to know less about politics compared to males; however, demographic variables, such as jobless, single, and childless, also play a role in determining the different degree of political knowledge, but only a few.

Another research which also relevant to gender and politics as contestation and competition is research conducted by Gneezy, Niederle, and Rustichini (2003). It is stated that female is less effective in competitive environments. This research is conducted by examining male and female performance through an experimental study with the piece-rate scheme, which evokes participants to reach the target due to promising incentives he/she would get after the study. These three pieces of research have shown that gender difference plays a significant role in politics, even in countries that apply to democracy for a long time. Thus, a comprehensive study (for Indonesia) to identify gender differences and political behaviors is needed to capture the obstacles in Indonesia's democratic system so that several improvements can be made to fix them, such as different campaign mechanisms and content for females and males.

Overall, the research implements a quantitative correlational design where all data collection is conducted through an online platform. As an attempt to examine the primary variables between male and female groups, the researchers apply the Psychological Orientation toward Politics Scale (POTP-S) developed by Adinugroho (in press). POTP-S is a self-report instrument constructed by applying three dimensions of POTP (Burns, Schlozman, \& Verba, 2001). Moreover, examination of POTP based on gender difference would also be accompanied by two other variables, educational background (social and political science vs. non-social and political science) and ethnicity (Tionghoa and non-Tionghoa). These two variables would also be predictors, along with gender as a primary variable in regression analysis. Educational background will affect participants' perspective in seeing politics, while categorization between Tionghoa and non-Tionghoa is made due to the argument that Tionghoa is one of the races in Indonesia who obtain various political and identity pressures (Ibrahim, 2013). All the items in POTP-S are constructed by considering Indonesian political culture and context. All of these sets of questions are administered by applying online from (g-form). All participants should complete all questions before they submit the answer. In the analysis step, the researchers conduct two statistical calculations and descriptive statistics to examine the difference between male and female groups. Based on the literature review and research framework that has been developed in previous paragraphs, researchers hypothesize that gender plays a significant role in predicting different scores in each dimension, where the female group tends to be lower in three aspects of POTP.

\section{METHODS}

Data are collected from the online panel, which is categorized into two sections. Section one is related to demographic questions to record gender identity (male vs. female), ethnicity (Tionghoa vs. nonTionghoa), and educational background (social and political science, non-social and political science). All of the questions are asked with close-ended questions. Before going through to the next session, participants are required to complete their answers. In specific for ethnicity, the researchers categorize it into two types, Tionghoa and non-Tionghoa, based on the argument stated by Suryadinata (2014), who indicates Tionghoa as one of the minorities in Indonesia. From the perspective of Indonesian political history, Tionghoa is a group who often obtained political abuse from the government and other ethnicities since the reformation in 1998-1999. Besides that, many forms of social prejudice and subtle discrimination are still happened nowadays, targeting Tionghoa citizens. In section two, participants are required to complete POTP-S with three dimensions. Data collection is conducted through online social networks (Facebook, Twitter, Path, and Instagram) and online links shared through digital applications (WhatsApp, Telegram, and e-mail).

POTP-S, as the main scale in the research, is a self-report instrument constructed by Adinugroho (2018) that applies Burns, Schlozman, and Verba's (2001) three-dimensional aspects, PK, PI, and PE. Examples of items in this scale can be seen in Table 1. These three dimensions are a comprehensive framework that explains political behavior from the psychological perspective because these three dimensions represent cognition (PK), emotion (PI), 
Table 1 Example of Items for Three Dimensions of POTP-S

\begin{tabular}{|c|c|c|c|}
\hline Dimension & Indonesia & English & Type of item \\
\hline Knowledge (PK) & $\begin{array}{l}\text { Indonesia mendeklarasikan } \\
\text { kemerdekaannya di Jakarta }\end{array}$ & $\begin{array}{l}\text { Indonesia declared its independence } \\
\text { in Jakarta }\end{array}$ & $\begin{array}{l}\square \text { True } \\
\square \text { False }\end{array}$ \\
\hline Interest (PI) & $\begin{array}{l}\text { Saya mencari tahu calon pejabat } \\
\text { yang memiliki kasus tertentu pada } \\
\text { masa lampaunya }\end{array}$ & $\begin{array}{l}\text { I try to find out a candidate who has a } \\
\text { case in the past }\end{array}$ & \multirow{3}{*}{$\begin{array}{l}1 \text { - Strongly disagree } \\
2 \text { - Disagree } \\
3 \text { - Rarely disagree } \\
4 \text { - Rarely agree } \\
5 \text { - Agree } \\
6 \text { - Strongly agree }\end{array}$} \\
\hline $\begin{array}{l}\text { Efficacy (PE) } \\
\text { - Internal (I) }\end{array}$ & $\begin{array}{l}\text { Suara saya berharga untuk proses } \\
\text { demokrasi di negeri ini (I) }\end{array}$ & $\begin{array}{l}\text { My voice is valuable for the } \\
\text { democratic process in my country (I) }\end{array}$ & \\
\hline - External (E) & $\begin{array}{l}\text { Saya rasa pemerintah melihat saya } \\
\text { sebagai kalangan yang memiliki } \\
\text { pengaruh terhadap kebijakan }(E)\end{array}$ & $\begin{array}{l}\text { I think government see me as a person } \\
\text { who can influence their policy (E) }\end{array}$ & \\
\hline
\end{tabular}

Note. POTP-S has been validated with confirmatory factor analysis methods (CFA; Adinugroho, 2018)

and belief (PE). Cognition refers to knowledge capacity (Fayn et al., 2017; Silvia, 2008) and efficacy as the expectation to positively contribute to politics (Bandura, 1977; 2013).

As an attempt to measure the variable, PE and PI are examined by statement item with the attitudinal scale from 1 (strongly disagree) until 6 (strongly agree) due to its nature as a non-ability state. All of the items are constructed using the Indonesian language started from theoretical construction up to item writing. This decision is based on the existing instrument, which also measured PI and PE (Shani, 2012; McDonnell, 2020). In opposite, $P K$ is measured by using the forced-choice item (true or false) due to the nature of knowledge as an ability in a psychological context. In this section, participants need to respond to the correct answer in each item. Table 1 describes the examples of items in POTP-S in each dimension.

The validity and reliability of this instrument have been examined through Confirmatory Factor Analysis (CFA) (Adinugroho, 2018). CFA is a Structural Equation Modeling (SEM) calculation by using statistical principle (factor loading) to examine the degree of contribution in each item developed by the test developer (Kline, 2015). Based on the CFA examination, it is decided to accept 22 items for the three dimensions. Goodness of Fit Statistics (GFS) is also conducted to examine the robustness of the model, which is derived from 22 final items, such as Root Mean Square Approximation (RMSEA) and Standardized Root Mean Square Residual (SRMR). RMSEA and SRMR refer to the statistical calculation to examine the quality of the model developed with the collected sample (Kline, 2015). Thereby, even though POTP-S is constructed by relying on western theory, the technical construction and development of this instrument rely on Indonesia's democratic situation. All political terms were applied by considering Indonesian context and knowledge on politics (i.e., Dewan Perwakilan Rakyat or DPR to represent parliament in Indonesia). The technical process in adopting the Indonesian context is crucial for a self-report instrument like POTP-S due to its nature in correlation with a specific context.
As for analyzing the data, Simple Linear Regression (SLR) with the hierarchical technique is applied in the research for examining the contribution of gender towards the outcome variable, POTP. SLR refers to the statistical calculation, which is able to calculate the magnitude of predictors variables with various statistical characteristics, such as nominal, ordinal, and interval (Chiarini \& Brunetti, 2019), towards one continuous outcome variable. Moreover, a three-block analysis SLR is applied in this research to examine three predictors, gender as primary predictor and ethnicity and educational background as secondary predictors that accompany gender. Gender as a primary predictor is categorized as a binary variable with two nominal indicators, 0 (male) and 1 (female). Similar to gender as the primary predictor, the researchers also categorize 0 and 1 for ethnicity (Tionghoa \& non-Tionghoa) and educational background (social and politics students and non-social and politics students). By applying a three-block analysis, it could be understood that the magnitude of predictor while it interacts with other variables (ethnicity and educational background).

\section{RESULTS AND DISCUSSIONS}

In total, 295 participants are involved in the research. Most of the participants are dominated by youngsters $(M=21,43 ; \mathrm{SD}=2,07)$, with the age range from 16 to 30 . In the aspect of gender, participants are dominated by the female $(68,7 \%)$ from various public and private universities in Jakarta, Depok, Tangerang, and Bekasi. All the collected participants have minimum senior high school grades for their educational background (SMA).

Comparison between males and females is undertaken by comparing mean scores between each dimension of POTP-S. Items in POTP-S refer to specific political activities that might be relevant in comparison between the male and female groups. These two groups have significant differences in the number of samples between males $(n=88)$ and 
females $(n=207)$. Statistical method t-test is applied in this phase to identify the degree of difference on each behavioral dimension of POTP between male and female groups. This method calculates the significance difference by comparing mean difference and statistical variance between groups (Gravetter \& Wallnau, 2017). The result in Table 2 indicates different patterns between males and females in the three dimensions. In general, the mean score indicates differences in all the three dimensions: PE, PK, and PI, even though the sample size is significantly different between the two groups. In the PI dimension, there are five topics of interest in politics, which emerge as categorization to differentiate the degree of interest between male and female groups (see Table 2). This result has confirmed the hypotheses, which indicate that the female group has lower POTP than the male group in Indonesia.

The difference between males and females has shown that gender issues in politics still emerge in Indonesia until recent days. Even though Indonesia has accepted democracy as its nation principle for over 20 years, democratic deprivation between males and females still exists, even in the educated sample. The inequality condition might bring some social and political consequences in policy and regulationmaking. Without proper equality between males and females, gender inequality will still occur. In this crisis situation, the government needs to think quickly and strategically to improve female participation in politics. A quick-win strategy needs to be developed to overcome this situation.

Results in Table 2 have indicated that the female group is positioned low in most aspects of POTP. In order to examine the contribution for those two covariates in the female group, ethnicity, and educational background, the researchers also conduct comparison analysis for POTP degree within the female group. Two covariates are used in this analysis process to examine the degree of difference in the female group. The result presented in Table 3 has shown the various differences in every aspect of POTP. Thus, the difference is also occurred even with a significant difference in sample size (see Table 3 ), both for ethnicity and educational background. Despite the significant difference between groups, the gender issue still exists based on specific categorization (ethnicity and educational background). In conclusion, ethnicity and educational background play a significant role in determining the POTP. From this result, the gender issue is a complex issue that needs to examine more sharply in various contexts across Indonesia (i.e., urban, rural, and religion).

As an attempt to make a statistical decision on the result in Table 3, the researchers apply an independent sample t-test (Ist) to compare the mean difference between two groups, Tionghoa with nonTionghoa (ethnicity group), and social and political science with non-social and political science in three aspects of POTP (education background group). Due to unequal sample sizes in both groups, the researchers rely on independent t-test calculation using equal variance, not assumed principle. Result from Ist calculation has shown PI $(\mathrm{t}(205)=2,41 ; \mathrm{p}<0,05)$ and PK $(\mathrm{t}(205)=2,22 ; \mathrm{p}<0,05)$, whereas in PE dimension, significant mean difference only occurs in internal PE $(\mathrm{t}(205)=1,99 ; \mathrm{p}<0,05)$. Whereas, in the educational background group, only PK $(\mathrm{t}(205)=3,02 ; \mathrm{p}<0,05)$, which showed the significant mean difference between the two.

Hierarchical multiple regression calculation is utilized by the researchers to examine the degree of magnitude in statistical solution on predictors (gender, educational background, and ethnicity) towards three dimensions of POTP. The researchers apply three blocks analysis based on our theoretical framework to

Table 2 Gender and Measures of POTP $(n=295)$

\begin{tabular}{cccc}
\hline Political activities (item No.) & Mean for Male (SD) & Mean for Female (SD) & Comparison t \\
\hline Political interest on; & $28,98(10,27)$ & $27,66(10,44)$ & $\mathrm{t}(293)=1,02$ \\
Government program (2) & $3,35(1,48)$ & $3,04(1,44)$ & $\mathrm{t}(293)=1,36$ \\
Corruption issue (3) & $3,85(1,43)$ & $3,55(1,42)$ & $\mathrm{t}(293)=1,7$ \\
Minister and Gov. Inst (7) & $3,25(1,53)$ & $3,09(1,39)$ & $\mathrm{t}(293)=-0,13$ \\
Political actor on TV (8) & $3,44(1,55)$ & $3,53(1,44)$ & $\mathrm{t}(293)=0,89$ \\
Political campaign (11) & $2,24(1,36)$ & $2,41(1,19)$ & $\mathrm{t}(293)=0,14$ \\
Political news on TV (14) & $2,93(1,59)$ & $2,53(1,39)$ & $\mathrm{t}(293)=0,67$ \\
Website on politics (15) & $3,55(1,53)$ & $3,26(1,54)$ & $\mathrm{t}(293)=2,1^{*}$ \\
Political efficacy; & $24,93(6,48)$ & $23,52(5,92)$ & $\mathrm{t}(293)=1,74$ \\
External & $13,61(4,30)$ & $13(3,67)$ & $\mathrm{t}(293)=2,15^{*}$ \\
Internal & $11,32(3,03)$ & $10,53(2,82)$ & $\mathrm{t}(293)=1,24$ \\
Political knowledge & $3,63(1,67)$ & $2,67(1,63)$ & $\mathrm{t}(293)=4,56^{*}$ \\
\hline
\end{tabular}

Note. Numerical values in the three dimensions indicate raw score derived from each item and total items for dimension. $* p<0,05$ 
Table 3 Measures of POTP in Female Group based on Ethnicity and Educational Background (n=207)

\begin{tabular}{ccccc}
\hline Political activities & \multicolumn{2}{c}{ Ethnicity } & \multicolumn{2}{c}{ Educational background } \\
\cline { 2 - 5 } & $\begin{array}{c}\text { Tionghoa } \\
(\mathbf{n = 1 3 1 )}\end{array}$ & $\begin{array}{c}\text { Non-Tionghoa } \\
(\mathbf{n = 7 6 )}\end{array}$ & $\begin{array}{c}\text { Soc \& Pol } \\
\text { Science (n=9) }\end{array}$ & $\begin{array}{c}\text { Non-Soc \& Pol } \\
\text { Science (n=198) }\end{array}$ \\
\hline Political interest on; & $26,39(10,04)$ & $29,82(10,44)$ & $33,66(8,74)$ & $27,38(10,03)$ \\
Government program (2) & $3,11(1,39)$ & $3,32(1,41)$ & $3,22(1,71)$ & $3,19(1,38)$ \\
Corruption issue (3) & $2,87(1,45)$ & $3,33(1,42)$ & $4,22(0,83)$ & $2,98(1,43)$ \\
Minister and Gov Inst (7) & $3,89(1,41)$ & $3,88(1,35)$ & $3,56(1,66)$ & $3,90(1,37)$ \\
Political actor on TV (8) & $2,90(1,33)$ & $3,41(1,43)$ & $4,33(1,65)$ & $3,03(1,35)$ \\
Political campaign (11) & $2,69(1,38)$ & $3,13(1,30)$ & $3,56(1,66)$ & $2,82(1,34)$ \\
Political news on TV (14) & $4,44(1,19)$ & $4,51(1,05)$ & $4,56(1,42)$ & $4,46(1,13)$ \\
Website on politics (15) & $2,47(1,36)$ & $2,63(1,44)$ & $2,78(1,78)$ & $2,52(1,37)$ \\
Political efficacy; & $22,97(6,18)$ & $24,47(5,35)$ & $27,55(6,52)$ & $23,34(5,85)$ \\
External & $10,35(2,91)$ & $10,82(3,67)$ & $12(2,82)$ & $10,45(2,81)$ \\
Internal & $12,62(3,76)$ & $10,53(2,82)$ & $15,55(4,58)$ & $12,88(3,58)$ \\
Political knowledge & $2,48(1,61)$ & $2,67(1,63)$ & $4,11(1,45)$ & $2,60(1,61)$ \\
\hline
\end{tabular}

Table 4 Gender, Ethnicity, and Educational Background and Its Contribution towards POTP

\begin{tabular}{lcccccccccc}
\hline & \multicolumn{3}{c}{ Political Interest } & \multicolumn{3}{c}{ Political Efficacy } & \multicolumn{3}{c}{ Political Knowledge } \\
\cline { 2 - 9 } & B & SE & $\boldsymbol{\beta}$ & B & SE & $\boldsymbol{\beta}$ & B & SE & $\boldsymbol{\beta}$ \\
\hline $\begin{array}{l}\text { Block 1 } \\
\text { Gender }\end{array}$ & 1,32 & 1,28 & 0,06 & 1,40 & 0,77 & 0,10 & 0,95 & 0,20 & $0,25^{* *}$ \\
$\begin{array}{l}\text { Block 2 } \\
\text { Gender }\end{array}$ & 1,52 & 1,26 & 0,06 & 1,52 & 0,76 & 0,11 & 0,98 & 0,20 & $0,26^{* *}$ \\
Ethnicity & 4,25 & 1,21 & $0,20^{*}$ & 2,36 & 0,73 & $0,18^{* *}$ & 0,54 & 0,19 & $0,15^{* *}$ \\
Block 3 & & & & & & & & & \\
Gender & 1,5 & 1,26 & 0,06 & 1,50 & 0,76 & 0,11 & 0,97 & 0,20 & $0,26^{* *}$ \\
Ethnicity & 3,80 & 1,26 & $0,18^{*}$ & 2,08 & 0,76 & $0,16^{* *}$ & 0,41 & 0,20 & $0,11^{*}$ \\
Education & 3,54 & 2,94 & 0,07 & 2,25 & 1,77 & 0,07 & 1,04 & 0,47 & $0,12^{*}$ \\
\hline
\end{tabular}

Note:

$\mathrm{R}$ Squared $=0,060$ for Step $1 ; \Delta \mathrm{R}^{2}=0,040$ for Step 2 and $\Delta \mathrm{R}^{2}=0,005$ for Step $3(\mathrm{p}<0,05)$ for PI

$R$ Squared $=0,011$ for Step $1 ; \Delta R^{2}=0,034$ for Step 2 and $\Delta R^{2}=0,005$ for Step $3(p<0,05)$ for PE

$R$ Squared $=0,066$ for Step $1 ; \Delta R^{2}=0,023$ for Step 2 and $\Delta R^{2}=0,015$ for Step $3(p<0,05)$ for PK

$* \mathrm{p}<0,05$.

$* * \mathrm{p}<0,01$.

identify gender as a single predictor and the contribution of covariates. The result in Table 4 has shown that PK is the most impacted variable by gender, ethnicity, and educational background. Whereas for PI and PE, only ethnicity (Tionghoa \& non-Tionghoa) is the only variable, which affects these two variables. Gender difference does not significantly affect PI and PE. Despite different results for the three variables, block analysis has shown a similar pattern among the three variables. When gender is combined with covariates, ethnicity, and educational background, the degree of impact on gender (See $\beta$ in Table 4 ) has increased from Block 1 into Block 2 and 3. Even though the degree is not significant, a similar empirical pattern occurs for the three variables. This result brings insight into the politics of identity (Haboddin, 2012; Arivia, 2014), which underlines that ethnicity, religion, and gender are parts of crucial identity related to Indonesia's political environment.

\section{CONCLUSIONS}

The result has shown that gender plays a role in determining PK for male and female groups. The regression calculation shows that $\mathrm{PK}$ is the most affected when gender appears as the predictor. Moreover, the interaction between gender and other two variables, ethnicity and education, also play a significant role in affecting the degree of PK. Females 
who identify themselves as Tionghoa and have nonsocial and political backgrounds tend to have lower POTP degrees than other female groups who are not. For further study, focusing on political attitudes and concrete participation (direct vs. indirect) can be an alternative to examine gender differences in politics more comprehensively.

Even though only PK is affected, knowledge about politics is also vital in determining the quality of democracy. Society, as the highest authority in the democratic country, needs to have a critical capacity to monitor the government and, most importantly, select the best candidate who is capable to act as the highest administrator. In order to produce those outputs, the critical capacity embedded in PK needs to be considered seriously by various stakeholders.

\section{REFERENCES}

Aars, J., \& Christensen, D. A. (2020). Education and political participation: The impact of educational environments. Acta Politica, 55(1), 86-102. https:// doi.org/10.1057/s41269-018-0101-5.

Adinugroho, I. (2018). Understanding psychological motives towards politics: Developing psychological orientation scale towards politics (POTP-S) for Indonesia. Journal of Government and Politics, 9(4), 487-510. https://doi.org/10.18196/jgp.9491.

Antara, A. (2017, March 15). Polisi proses 6 kasus konflik Pilkada 2017 Intan Jaya. Retrieved from https:// news.okezone.com/read/2017/03/15/340/1643006/ polisi-proses-6-kasus-konflik-pilkada-2017-intanjaya.

Arivia, G. (2014). Stereotip ibu negara \& karir yang disembunyikan: Kajian peranan dan persepsi istri capres-cawapres pada pemilihan presiden 2014. Jurnal Perempuan, 19(3), 183-189.

Bandura, A. (1977). Self-efficacy: Toward a unifying theory of behavioral change. Psychological Review, 84(2), 191-215. https://psycnet.apa.org/doi/10.1037/0033295X.84.2.191.

Bandura, A. (2013). The role of self-efficacy in goalbased motivation. In E. A. Locke \& G. P. Latham (Eds.), New Developments in Goal Setting and Task Performance (pp. 147-157). London: Routledge/ Taylor \& Francis Group.

Burns, N., Schlozman, K. L., \& Verba, S. (2001). The private roots of public action: Gender, equality, and political participation. USA: Harvard University Press.

Chiarini, A., \& Brunetti, F. (2019). What really matters for a successful implementation of lean production? A multiple linear regression model based on European manufacturing companies. Production Planning \& Control, 30(2), 1-11. http://dx.doi.org/10.1080/0953 7287.2019.1589010.

Coffé, H. (2013). Women stay local, men go national and global? Gender differences in political interest. Sex Roles, 69, 323-338. https://doi.org/10.1007/s11199013-0308-x.
Dahl, V., Abdelzadeh, A., \& Sohl, S. (2018). The moderating role of political interest: Investigating involvement in institutional and non-institutional political participation among young adults in Sweden. PCS: Politics, Culture and Socialization, 7, 21-22. https:// doi.org/10.3224/pcs.v7i1-2.09.

Dalton, R. J. (2009). Citizen politics. Washington: CQ Press. de Zúñiga, H. G., Diehl, T., \& Ardévol-Abreu, A. (2017). Internal, external, and government political efficacy: Effects on news use, discussion, and political participation. Journal of Broadcasting \& Electronic Media, 61(3), 574-596. http://dx.doi.org/10.1080/08 838151.2017 .1344672$.

Dejaeghere, Y., \& van Erkel, P. (2017). The importance of issue-ownership and salience for voters' knowledge of parties' issue positions. Electoral Studies, 46, 15-25. http://dx.doi.org/10.1016/j. electstud.2016.11.020.

Dolan, K. (2011). Do women and men know different things? Measuring gender differences in political knowledge. The Journal of Politics, 73(1), 97-107.

Ekayanta, F. B. (2019). Intellectuals in post-Soeharto politics. Jurnal Politik, 5(1), 143-148.

Ekman, J., \& Amnå, E. (2012). Political participation and civic engagement: Towards a new typology. Human Affairs, 22(3), 283-300. https://doi.org/10.2478/ s13374-012-0024-1.

Fayn, K., Silvia, P. J., MacCan, C., \& Tiliopoulos, N. (2017). Interested in different things or in different ways? Exploring engagement distinction between openness and intellect. Journal of Individual Differences, 38(4), 265-273. http://dx.doi.org/10.1027/1614$0001 / \mathrm{a} 000243$.

Ferrín, M., Fraile, M., \& García-Albacete, G. M. (2019). Adult roles and the gender gap in political knowledge: A comparative study. West European Politics, 42(7), 1368-1389. https://doi.org/10.1080/ 01402382.2019.1577069.

Flavin, P., \& Keane, M. J. (2012). Life satisfaction and political participation: Evidence from the United States. Journal of Happiness Studies, 1, 63-78. https://doi.org/10.1007/s10902-011-9250-1.

Fossati, D. (2016). The state of local politics in Indonesia: Survey evidence from three cities. Singapore: ISEAS Publishing.

Galston, W. A. (2001). Political knowledge, political engagement, and civic education. Annual Review of Political Science, 4, 217-234. https://doi. org/10.1146/annurev.polisci.4.1.217.

Gneezy, U., Niederle, M., \& Rustichini, A. (2003). Performance in competitive environments: Gender differences. The Quarterly Journal of Economics, 118(3), 1049-1074. https://doi. org/10.1162/00335530360698496.

Gravetter, F., \& Wallnau, L. (2017). Statistics for the behavioral sciences. USA: Cengage Learning.

Haboddin, M. (2012). Menguatnya politik identitas di ranah lokal. Jurnal Studi Pemerintahan, 3(1), 116-134. https://doi.org/10.18196/jgp.2012.0007.

Ibrahim, I. (2013). Tionghoa Indonesia: Dari dikotomi ke mono-identitas? Society, 1(1), 46-55. https://doi. 
org/10.33019/society.v1i1.41.

Johann, D. (2012). Specific political knowledge and citizens' participation: Evidence from Germany. Acta Politica, 47, 42-66. https://doi.org/10.1057/ ap.2011.20.

Kline, R. B. (2015). Principles and practice of structural equation modeling. USA: The Guilford Press.

McDonnell, J. (2020). Municipality size, political efficacy and political participation: A systematic review. Local Government Studies, 46(3), 331-350. https:// doi.org/10.1080/03003930.2019.1600510.

Meiliana, D. (2018, January 15). Kalbar dan Papua paling rawan konflik di Pilkada 2018, Polri akan kuatkan pengamanan nasional. Retrieved from https:// nasional.kompas.com/read/2018/01/16/06080591/ kalbar-dan-papua-paling-rawan-konflik-di-pilkada2018-polri-akan-kuatkan.

Pruysers, S., Blais, J., \& Chen, P. G. (2019). Who makes a good citizen? The role of personality. Personality and Individual Differences, 146(5), 99-104. http:// dx.doi.org/10.1016/j.paid.2019.04.007.

Shani, D. (2012). Measuring political interest. In J. H. Aldrich., \& K. M. McGraw., Improving Public Opinion Surveys: Interdisciplinary Innovation and the American National Election Studies (pp. 137157). Oxford: Oxford University Press.

Silvia, P. J. (2008). Interest - The curious emotion. Current Directions in Psychological Science, 17(1), 5760. https://psycnet.apa.org/doi/10.1111/j.14678721.2008.00548.x.

Strabac, Z., \& Aalberg, T. (2011). Measuring political knowledge in telephone and web surveys: A cross-national comparison. Social Science Computer Review, 29(2), 175-192. https://doi.
org/10.1177\%2F0894439310371340.

Sulemana, I., \& Agyapong, E. (2019). Subjective well-being and political participation: Empirical evidence from Ghana. Review of Development Economics, 23(3), 1368-1386. https://doi.org/10.1111/rode.12592.

Suryadinata, L. (2014). Kebijakan negara Indonesia terhadap etnik Tionghoa: Dari asimilasi ke multikulturalisme? Jurnal Antropologi Indonesia, 71, 1-12. https://doi. org/10.7454/ai.v0i71.3464.

Suryowati, E. (2017, November 7). Pilkada serentak 2018, jenis konflik terbanyak ada di Jawa Timur dan Papua. Retrieved from https://nasional.kompas. $\mathrm{com} / \mathrm{read} / 2017 / 11 / 07 / 19253381 /$ pilkada-serentak2018-jenis-konflik-terbanyak-ada-di-jawa-timurdan-papua?page $=$ all.

The Economist. (2018). Democracy index 2017: Free speech under attack. Retrieved from https://www.eiu.com/public/topical_report. aspx?campaignid=DemocracyIndex2017.

Valentino, N. A., Brader, T., Groenendyk, E. W., Gregorowicz, K., \& Hutchings, V. L. (2011). Election night's alright for fighting: The role of emotions in political participation. The Journal of Politics, 73(1), 156-170. https://doi.org/10.1017/ S0022381610000939.

Verba, S., Burns, N., \& Schlozman, K. L. (1997). Knowing and caring about politics: Gender and political engagement. The Journal of Politics, 59(4), 10511072. https://doi.org/10.2307/2998592.

Zaheer, L. (2016). Effects of watching political talk shows on political efficacy and political participation. Journal of Political Studies, 23(2), 357-357. 